\title{
Material Analysis of 120 mm Mortar Projectile Stabilizer
}

Zbyněk Studeny, Zdenek Pokorny, David Kusmič, Emil Svoboda

Faculty of Military Technology, University of Defence, Kounicova 156/65, 66210 Brno, Czech Republic. E-mail: zbynek.studeny@unob.cz

The article deals with the evaluation the state of $120 \mathbf{~ m m}$ mortar projectile stabilizer. It assesses a crashed projectile, whose stabilizer got stuck in the barrel during the shot. The evaluation includes the analysis of the mechanical properties, especially hardness, besides the evaluation of cracks, structure and chemical composition of the materials used. Cracks are documented with Olympus GX 51 optical microscope and Tescan Vega TS 5135 electron microscope. The chemical composition was assessed by EDS method on the Noran System Six/300 device. The hardness values of the stabilizers were obtained by LECO LV800AT hardness tester, the microhardness measurement used LECO LM247AT equipment. Material properties and microstructure evaluation was compared with the documents available in the metallurgical laboratory of the Department of Mechanical Engineering.

Keywords: $120 \mathrm{~mm}$ mortar projectile stabilizer, woody crack.

\section{Acknowledgement}

The article was composed with the financial support of "Project Development Organization" at the Department of Mechanical Engineering, FVT, UO Brno.

\section{References:}

[1] ČSN 42 4222: Slitina hliníku tvářená - Formed aluminium alloy - 424222 AlZn6Mg2Cu. 1978

[2] ČSN EN ISO 6507-1 (420374): Kovové materiály - Zkouška tvrdosti podle Vickerse - Č́st 1: Zkušební metoda. 2006 - Metallic materials - Vickers hardness test - Part 1: Test method 2006

[3] ČSN EN ISO 6506-1(420359): Kovové materiály - Zkouška tvrdosti podle Brinella - Část 1: Zkušební metoda. 2006 Metallic materials - Brinell hardness test - Part 1: Test method. 2006

[4] ČSN EN ISO 18265 (420379): Kovové materiály - Převod hodnot tvrdosti. 2006 - Metallic materials - Conversion of hardness values. 2006

[5] STUDENÝ, Z., HRUBÝ, V., SVOBODA, E., POSPÍCHAL, M., ADAMEC, M. (2012). Material analysis of $120 \mathrm{~mm}$ mortar barrel type 82. In: Armament and technics of land forces 2012 18th international scientific conference, p. 119-126, ISBN 978-80-8040-458-1. Liptovský Mikuláš, Slovak Republic.

[6] STUDENÝ, Z., KUSMIČ, D., SVOBODA, E., POSPÍCHAL, M., HRUBÝ, V. (2013). Material analysis of $125 \mathrm{~mm}$ tank main gun type TK 2A46. In: International Conference on Military Technologies, p. 1549-1557, ISBN 978-80-7231-918-3. Brno, Czech Republic.

[7] KUSMIČ, D., STUDENÝ, Z., HRUBÝ, V., SVOBODA, E. (2014). Material analysis of demaged 125mm tank main gun type TK 2A46. Science and Military, vol. 9, no. 1, p. 26-32. ISSN 1336-8885. Slovak Republic.

[8] KOPAS. P., SÁGA, M. (2013). In-phase multiaxial fatigue experimental analysis of welded cylindrical 6063-T66 aluminium alloy specimens. Manufacturing Technology, vol. 13, no.1, p. 59-64. ISSN 1213-2489. Czech Republic.

[9] HRICOVÁ, J. (2013). Influence of Cutting Tool Material on the Surface Roughness of AlMgSi Aluminium Alloy. Manufacturing Technology, vol. 13, no.3, p. 324-329. ISSN 1213-2489. Czech Republic.

[10] NÁPRSTKOVÁ, N., SVOBODOVÁ, J., CAIS, J. (2013). Influence of strontium in AlSi7Mg0.3 alloy on the tool wear. Manufacturing Technology, vol. 13, no.3, p. 368-373. ISSN 1213-2489. Czech Republic. 